\title{
The Influence of Affective Commitment on Citizenship Behavior and Intention to Quit among Commercial Banks’ Employees in Nigeria
}

\author{
Akinyemi Benjamin $^{1}$ \\ ${ }^{1}$ Department of Human Resource Management, School of Finance and Banking, Kigali, Rwanda \\ Correspondence: Akinyemi Benjamin, Department of Human Resource Management, School of Finance and \\ Banking, Kigali, Rwanda. Tel: 250-783-468-279. E-mail: akinyemi.ben@gmail.com
}

Received: March 29, 2012 Accepted: April 18, 2012 Online Published: May 24, 2012

doi:10.5539/jms.v2n2p54 URL: http://dx.doi.org/10.5539/jms.v2n2p54

\begin{abstract}
The purpose of this study was to investigate the influence of affective commitment on discretionary work behaviour and intention to quit among employees in selected post-consolidation Nigerian commercial banks. Using the quantitative approach, data were collected through a structured questionnaire administered to full-time employees of eight Nigerian post-consolidation era commercial banks out of which 303 were returned. The research results, based on respondents' perceptions, revealed that affective commitment had a statistically significant relationship with organizational citizenship behavior and voluntary turnover intentions. The practical organizational and managerial implications of the results were discussed.
\end{abstract}

Keywords: affective organizational commitment, organization support theory, turnover intentions, citizenship behaviour

\section{Introduction}

Gaining and sustaining the competitive edge is the super-ordinate goal of local and global commercial enterprises. However, intense competition, changing legal requirements, war for talent, short product life cycle, rapidly changing technology, changing customer demands and expectations and unstable global economic landscape continue to put immense pressure on contemporary business organizations. Intangible assets have emerged as the most effective and reliable source of growth and competitive advantage in the current volatile business environment. No organization rises above the overall quality of its human resource. For organizational success and competitive advantage human capital is the key factor being the major driver of change, innovation and organizational sustainability. Kessels (2009) argues that gaining and sustaining the competitive edge no longer depend organizations' tangible but intangible assets which are only found in human resource. Organizations that thrive in chaos rely heavily on the collective skills, knowledge and abilities of their workforce. Employees' commitment to their organizations, willingness to exhibit discretionary work behavior and decision to remain with the organization are critical success factors for organizations to gain and sustain the competitive edge in spite of daunting challenges they face.

Organizations of the $21^{\text {st }}$ century are concerned about how to foster employee commitment, extra-role behaviour and retention in a highly competitive environment. Organizational success and sustainability require exceptional contributions from the workforce. Employees need to go beyond the call of normal duty to generate novel ideas and see it through to commercialization. This is only possible when organizations, through innovative human resource practices, secure employees' unalloyed commitment, citizenship and continuance with organizations. It is essential to note that organizations do take a different approach. They are increasingly requiring their employees to work longer and longer hours (Bond, et al., 1997; Reich, 2001; Schor, 1991), and Nigerian post-consolidation banks are not an exception. However, organizations that will place a great deal of importance on the level of employees' engagement and commitment are the only ones that grow and remain competitive.

This paper explores the influence of affective commitment on citizenship behavior and turnover intentions. It is divided into the following sections: Introduction, Background, Methodology, Result of Data Analysis, Discussion and Conclusion and Organizational and Managerial Implications of the results. 


\section{Background}

\subsection{Organizational Commitment}

According to Lee, Carswell, and Allen (2000) understanding the construct of occupational commitment is very important because: a) people's jobs are major focus' of their lives, b) the possible link to keeping one's job or relationship with the organization, c) possible relationships to work performance, and (d) "the understanding of how people develop, make sense of, and integrate their work related commitments” (p. 799). Organizational Commitment is considered to be more stable and less subject to daily fluctuations making it more important than job satisfaction in understanding employee behavior (Angle and Perry, 1983; Mowday, Steers, and Porter, 1982).

Scholars differ on an exact definition of commitment (Buchanan, 1974; Porter, et al., 1974; Sheldon, 1971; Siegel and Sisaye, 1997). It has been defined in a variety of ways (Griffin and Bateman, 1986; Mathieu and Zajac, 1990; Morrow, 1983) such as, an attitude or an orientation linking the identity of an employee to the organization, a process by which organizational and employee goals become congruent, an involvement with a particular organization, the costs associated with leaving, and normative pressures to act in a way which meets organizational goals (Meyer and Allen, 1997). Commitment has also been specifically described as: psychological state (Allen and Meyer, 1990, p.14), psychological attachment (O’Reilly and Chatman 1986, p.493) or "psychological bond" (Matthieu and Zajac, 1990, p.171). According to Meyer and Herscovitch (2001, p. 30), it is a "stabilizing or obliging force, that gives direction to behaviour (e.g. restricts freedom, binds the person to a course of action)."

Meyer and Allen (1991) conceptualised three dimensions of organizational commitment: affective, normative and continuance commitment. Affective commitment is "...the employee's emotional attachment to, identification with, and involvement in the organization" (p. 67). Normative commitment refers to the responsibility one has for the organization, while continuance commitment is an employee's opportunity cost of leaving the organization. Meyer and Allen's three dimensional organizational commitment model is most widely accepted and used.

\subsection{Affective Commitment (AC)}

AC emphasizes an individual's identifification and involvement in the organization (Porter, Seers, Mowday and Boulian, 1974). Employees with a strong AC continue employment with the organization because they want to do so" (Meyer and Allen, 1997, p. 67). This component of commitment is seen as "the most beneficial in enhancing organizational effectiveness" (Zeidan, 2006 p. 17). It is "an emotional attachment, with a volitional desire for involvement, and alignment of individual and organizational values. Buchanan (1974, p.533) refer to it as a "partisan, affective attachment to the goals and values of the organization, to one's role in it, to its goals and values, and to the organization for its own sake, apart from its purely instrumental worth.” This emotional attachment is positive in nature and appears to derive from conditions such as fairness, support from senior staff and colleagues, as well as value for individual worth and contributions” (Staples and Barlett, 2003).

Researchers have identified it as an antecedent of organizational citizenship behavior (Organ \& Ryan, 1995; Schappe 1998; Wasko \& Faraj, 2005) and also of absenteeism, performance and turnover (Mathieu and Zajak, 1990; Meyer and Allen, 1997; Mowday et al, 1982) but turnover is most strongly related to AC (Allen and Meyer, 1997). Affect-based commitment is, therefore, less likely to result in withdrawal behaviour and resistance to change (Meyer and Allen, 1997 and Iverson and Buttigieg, 1999). It aids the stability of organizational workforce as well as the quality and quality of output.

\subsection{Organization Support Theory and AC}

This study draws upon the organizational support theory (Eisenberger, et al., 1986; Rhoades and Eisenberger, 2002; Shore and Shore, 1995) which seems to give an insight into employee emotional attachment to their organizations. Research on Perceived Organization Support (POS) is based on the reciprocity norm of managers showing concern for employee's commitment to the organization and employees focusing on the organization's commitment to them. Employees expect to derive socioemotional resources, such as respect and caring, and tangible benefits, such as wages and medical benefits from the organization.

Researchers have found a strong relationship between POS and AC (Allen, et al., 1999; Eisenherberger, Fasolo, and Davis-LaMastro, 1990; Guzzo, Noonan, and Elron, 1994; Hutchiison, 1997; Hutchison and Garstka, 1996; Jones, Flynn, and Kelloway, 1995; Settoon, Bennett, and Liden, 1996; Shore and Tetrick, 1991; Shore and Wayne, 1993; Wayne et al., 1997). POS and AC are also reported to have similar antecedents and consequences (Rhoades, et al., 2001). A meta-analysis of research on POS by Rhoades and Eisenberger (2002) identified three general categories of favorable treatment received by employees (fairness of treatment, supervisors support, and 
rewards and job conditions). While these are positively related to POS, POS is also associated with outcomes favored by employees (e.g., increased job satisfaction, positive mood, and reduced stress) and the organization (e.g., increased AC and performance and reduced turnover). Behavioral outcomes of POS would, therefore, include increases in inrole and extra-role performance and decreases in stess and withdrawal behaviors such as absenteeism and turnover.

In relation to performance reward expectancies, Eisenberger et al. (1990) suggested that POS would indicate the organization's willingness to notice and reward employees' efforts to help the organization succeed. In the same vein, they also found a positive relationship between POS and performance reward expectancies. In essence the association between POS and AC has strong empirical support and ultimately result in decrease in employee withdrawal behaviors and increased extra-role behaviors.

\subsection{Antecedents and Consequences of $A C$}

AC as an individual employee attitude refers to feelings of belonging and sense of attachment to the organization and it has been related to personal characteristics, organizational structures, and work experiences, for example; pay, supervision, role clarity and skill variety (Hartmann, 2000). In a review of previous studies, Meyer and Allen (1997) found organizational characteristics, such as, organizational justice (Konovsky and Cropanzano, 1991), pay and procedural justice (Schaubroeck, et al., 1994; Pare and Tremblay, 2007), strategic decision making (Kim and Mauborgne, 1993), and upward communication (Konovsky and Cropanzano, 1991; Greenberg, 1994) have been positively related to AC.

AC has been positively related to work effort and performance (e.g., Bycio et al., 1995; Ingram et al., 1989; Luchak and Gellatly, 2007; Sager and Johnston, 1989; Vandenberghe et al., 2004) and positively related to in-role job performance and extra-role behavior (Meyer, et al., 1989). On the other hand, it is negatively related to absenteeism, intention to leave, and turnover (Alexandrov et al., 2007; Loi et al., 2006; Paré and Tremblay, 2007; Steers, 1977; Ugboro, 2006; Vandenberghe et al., 2004). Meyer and Allen (1997) suggested that employees having strong AC work harder and perform better than employees whose AC is weak.

Zannad and Rouet (2003) suggested that elements, such as: task autonomy, task significance large job scope, opportunities to grow and to learn rapidly, participation in decision-making, decentralization, high skill level of subordinates, good opportunities for social interaction, feeling of contribution to the company's development, challenging objectives, feeling of control over one's own destiny, opportunity to develop new technologies, performance-related rewards, high reactivity in human resources practices, low degree of formalization and procedures, a spirit of adventure" and lack of functional barriers "should contribute to an enhanced AC (attachment to work organization) in innovative company as compared to traditional ones” (p. 19).

It is essential, therefore, for contemporary organizations to develop and implement such human resource policies and practices that promote employee AC. The potential benefits of this are multifarious: identification with organizational values, higher productivity, enhanced quality of output and better overall organizational performance.

\subsection{Voluntary Turnover Intentions (VTI)}

Employees' turnover intentions has been the major focus of scholars, practitioners and researchers in diverse fields (Lambert, Hogana, and Bartona, 2001). A number of studies relating to intent to leave or turnover has been done (Koch and Steers, 1978; Lee and Bruvold, 2003). Turnover intentions is defined as the conscious and deliberate willingness to leave the organization (Tett and Meyer, 1993). It is the strongest precursor to actual turnover. Research findings have confirmed a strong link between turnover intentions and actual turnover. When valuable employees voluntarily leave organizations, it is generally considered detrimental in terms of replacement costs and work disruption (Addae et al., 2006).

Turnover intention has been highlighted as a key element in the modeling of employee turnover behavior. Although organizational commitment has been identified as a predictor of turnover intention (Arnold and Feldman, 1982; Hollenbeck and Williams, 1986), scholars have determined that the single best predictor of turnover is behavioral intentions (Fishbein and Ajzen, 1975; Abrams, et al., 1998; Bedeian, et al., 1991; Bluedorn, 1982; Lee and Mowday, 1987; Michaels and Spector, 1982). There is strong empirical evidence in support of the view that intent to stay or leave is strongly and consistently related to voluntary turnover (Dalessio, et al., 1986, Griffeth and Hom 1988; Mathieu and Zajac 1990). However, some studies have indicated that a notable decrease in organizational commitment and job satisfaction preceded eventual or actual turnover (Porter et al., 1974; Carmeli and Gefen, 2005; Clugston, 2000). Most researches are concerned with voluntary turnover in organizations and it is commonly held that voluntary turnover is dysfunctional, adversely influencing organizational effectiveness, i.e. 
the degree to which organizations achieve their goals (Hom and Griffeth, 1995).

\subsection{Organizational Citizenship Behavior (OCB)}

Interest in OCB dates back to Barnard's (1938) concept of the "willingness to cooperate” and Katz's distinction between dependable role performance and "innovative and spontaneous behaviors" (Katz, 1964; Katz and Khan, 1966). OCB has been the focus of numerous studies (e.g., Organ and Konovsky, 1989; MacKenzie, et al., 1991; Niehoff and Moorman, 1993; Organ and Ryan, 1995; Lievens and Anseel, 2004).

The term, OCB was first introduced by Bateman and Organ (1983) refering to it as "individual behavior that is discretionary, not directly or explicitly recognized by the formal reward system, and in aggregate promotes the effective functioning of the organization” (Organ, 1988 p.4). This definition implies that, a) the behavior is discretionary; b) it is not directly or explicitly recognized by the formal reward system; and c) in the aggregate, the behavior promotes the effective functioning of the organization (Zeidan, 2006). Podsakoff, et al. (2000) identified seven common OCB themes, viz: helping behavior, sportsmanship, organizational loyalty, organizational compliance, individual initiative, civic virtue and self-development. OCB is a behavior that goes beyond normal routine expectations (Daniels, et al., 2006).

According to Schnake (1991), OCB are not affected by organizational influences for three reasons: a) OCB are subtle and therefore hard to objectively rate, which makes for difficult inclusion in appraisals; b) Some forms of OCB may pull people away from their own work to assist another; and c) Since OCB cannot be contractually required (if they were required behaviors, they would be contractual behaviors, not OCB), the organization cannot punish employees for not performing them. Therefore, OCB is commonly defined in terms of social exchange (Moorman, 1991).

The burgeoining interest in OCB among scholars and practitioners is due to various reasons. It leads to better organizational performance and employee retention (Werner, 1994; Podasakoff, and Mackenzie, 1994; Podasakoff, et al., 1997; Walz and Niehoff, 2000). Secondly, an innovative organizational environment which today's organizations need for creating the competitive edge cannot be built through reliance on and compliance with written roles and behaviours. For organizations to survive and thrive in the dynamic business environment spontaneity is critical and this underscores the importance of extra-role behaviour (Wyss, 2006).

Furthermore, OCB is seen to improve organizational efficiency and effectiveness by contributing to resource transformation, innovation, and adaptability in environments demanding complex, ambiguous, and team-oriented work (Organ, 1988; Organ et al., 2005). For example, cooperation with peers, performing extra duties without complaint, punctuality, volunteering and helping others, using time efficiently, conserving resource, sharing ideas and positively representing the organization are practical consequences of OCB (Turnipseed and Rassuli, 2005).

Still underscoring the significance of OCB, Katz (1964) identified three basic conditions (pertaining to employees) that organizations must possess to operate efficiently: (1) participating and staying in the organization, (2) acting according to the behavioral principles regulated by the organization; and the most important condition, (3) automatic devotion to the organization.

Having established the indispensability of OCB to organizational performance it is essential to now examine the relationship between AC and OCB. The influence of AC on OCB has been a well researched area. Past studies have detailed the positive correlation between AC and OCB (Allen and Meyer, 1996; Mathieu and Zajac, 1990; McFarlane and Wayne, 1993; Haque and Aslam, 2011). AC was regarded as a predictor of OCB (Scholl, 1981; Wiener, 1982). In a meta-analytic study of the antecedents, correlates and consequences of organizational commitment, AC $(\rho=.32)$ correlated positively with OCB (Meyer, et al., 2002). AC was also regarded as an important factor for predicting extra-role behaviors, such as OCB (Scholl, 1981; Wiener, 1982).

Freund (2004) examined the relationship between work commitment and OCB among lawyers in the private sector. The results show that AC and OCB are significantly related. It should, however, be noted that some other studies have found no correlation between AC and OCB (Williams and Anderson, 1991; Shore and Wayne, 1993). In spite of these differing results it is generally held by scholar-practitioners and researchers that more research evidence supporting a positive relationship between AC and OCB lend credence to the assertion that AC has correlation with OCB.

Only a few studies, linking AC to OCB, have been conducted in non-Western context (e.g., Chien and Su, 2009; Su and Hsiao, 2005; Ogba, 2006). Most of the studies on OCB's relationship with other variables have focussed on western countries (e.g., Cappelli and Rogovsky, 1998; Drago and Carvey, 1998; Farh et al., 1990; Pearce and Gregersen, 1991; Samuel and Aubrey, 2006) using Western measures. These measures are used widely because of their validity and reliability, the applicability of such scale with similar results in non-western cultures 
(countries) have proved problematic (Cheng and Stockdale, 2003; Lee et al., 2001; Gautam et al., 2001; Wasti, 2002, Ogba, 2006).

In Nigeria, particularly, there is a dearth of empirical investigation on the relationship between employee commitment, OCB and VTI. Munene (2008) examined some correlates of OCB in Nigeria and reported that job involvement and AC had the highest zero order correlation. Ogba (2006) focussed on the impact of income and age on employee commitment in the Nigerian banking sector and concluded that the relationships between age, income and commitment might be explained by reference to cultural factors which might have stronger influence on employee expression of commitment to their organizations. Akinbode (2011) examined demographic and dispositional characteristics as predictors of (OCB) among Nigerian workgroups, a non-English culture. Results indicated that personality traits of extraversion and openness significantly predict workers' (OCB).

The current study is carried out within the African context using the case of Nigeria's thriving, rapidly changing and highly competitive banking sector. Nigerian banks are struggling to survive in the current volatile business environment. In this circumstance, the potential benefit of AC and OCB must be well understood and tapped by all managers and top executives. With AC and OCB employees are able to put the interest of organization above personal interest, work diligently, sacrificially and proactively, unleash creative and innovative potentials, defend the organization when necessary and stay with the organization in turbulent times while actively participating in efforts to salvage it. AC and OCB, indeed, key to organizational success and long-term sustainability.

\subsection{AC and OCB as Panacea to High Risk Environment Challenges}

The Nigerian Banking Sector is the second major contributor to national economic growth after the oil and gas sector. Banks are generally described as operating in a high risk environment which is capable of undermining their reputation and Nigeria's post-consolidation era commercial banks are not an exception. Owojori, et al., (2011) highlight the major risks facing the banks as: operational, reputational and human resource risks. Operational risk "is the risk of direct and indirect loss resulting from inadequate or failed internal processes people and systems or external threats generate. Operational risk may include frauds” (p. 26). Reputational risk occurs when the public loses trust and confidence which banks are expected to cultivate and safeguard. Human resource risk is "the risk that a bank may not have adequate human resources in terms of number, qualification and experience, to pursue its mandate. The risk should also cover losses to the bank occasioned by errors of commission and omission by staff. In addition, it includes losses to the banks arising from outright theft, frauds and forgeries" (p. 29).

This highlights the need for an empirical study of this nature that underscores the critical role of AC and OCB as a highly effective panacea, particularly, for organizations operating in high risk environment. Organizations that foster this attitude and behavior among their employees are most likely to mitigate the risks, create and sustain the competitive edge in turbulent times.

In a highly competitive service industry such as the banking sector, the ability to outperform competitors through new unique product development, excellent customer service, retention of top performers, is highly desirable. AC and OCB result in passionate service, deep interest and dedication which have positive impact on organizational performance.

\section{Methodology}

The survey research design method was used in this study. It involves the use of questionnaire in collecting data from the respondents. A total of 303 employees belonging to eight recapitalized commercial banks located in the Southwestern part of Nigeria responded to a questionnaire which measured AC, OCB and VTI. The banks surveyed were among the surviving commercial banks that succeeded in fulfilling the new mandatory minimum capital base of twenty-five billion Naira.

\subsection{Research Instruments}

The AC sub-scale of Allen and Meyer's (1993) organizational commitment instrument was used. Sample items included "I enjoy discussing my organization with people outside of it" and "This organization has a great deal of personal meaning for me."

OCB was measured using a 5-item scale adopted from Podsakoff et al. (1990) and Williams and Anderson (1991). Specifically, respondents were asked to their own helping behaviors on 5-point Likert-type scales. Sample items of OCB include: "I help colleagues who have been absent from work," and "I am mindful of how my behavior affects other people's job.”

A four-item scale adapted from the Michigan Organizational Assessment Questionnaire was used in measuring 
VTI (Camman, et al., 1979; Seashore, Lawler, et al., 1982) and the Lyons' Propensity to Leave scale (Cook, et al., 1981). Scale items include: "I plan to work at my present job for as long as possible" and "I will most certainly look for a new job in the near future."

Possible responses were arrayed on a five-point Likert scale comprising "strongly disagree" (5), "disagree" (4), "neutral" (3), "agree" (2), and "strongly agree" (1).

\subsection{Questionnaire Administration}

Five hundred questionnaires were administered to full-time employees of eight post-consolidation era commercial banks located in the South-Western part of Nigeria. Respondents preferred anonymity as they did not want to be linked openly with the research activity. It took four months to carry out the field work. At the end of the exercise, a total number of 303 questionnaires were returned.

\subsection{Data Analysis}

Data analysis was carried out by using Statistical Package for Social Scientists (SPSS) for Windows. To test the hypotheses, the mean, variance, standard deviation and Pearson Product Moment Correlation Coefficient of all variables were calculated. To evaluate the reliability of the results the $R^{2}$ is reported. $R^{2}$ is the square of the Pearson product moment correlation coefficient through data points in AC (independent values $-x$ ) and OCB and, VTI (dependent values $-y$ ). The $\mathrm{r}^{2}$ value can be interpreted as the proportion of the variance in $y$ attributable to the variance in $x$. As an indicator from 0 to 1 , it is most reliable when its value is at or near 1 .

\subsection{Research Model}

Based on the purpose of this study, i. e. examining the influence of AC on OCB and VTI, a research model below (Figure 1) was designed:

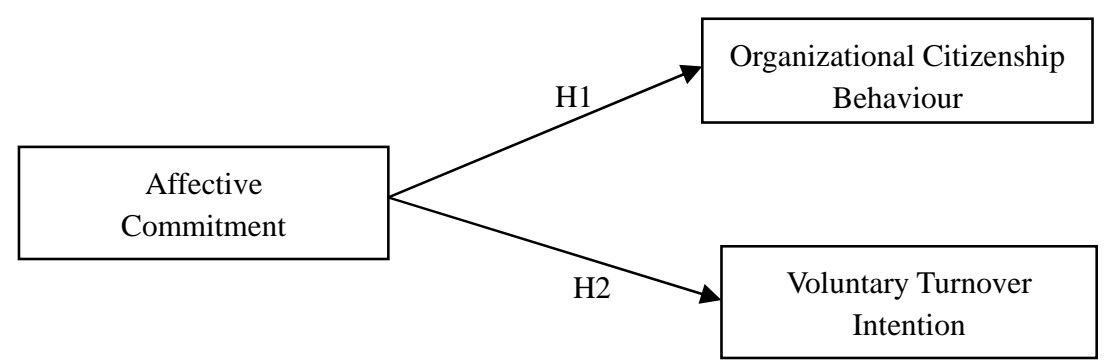

Figure 1. Research model

\subsection{Research Hypotheses}

The study aims to statistically test two research hypotheses, viz:

Hypothesis 1: There is no statistically significant positive relationship between AC and OCB.

Hypothesis 2: There is no statistically significant positive relationship between AC and VTI.

\section{Result of Data Analysis}

Data analysis was carried out using the Statistical Package for Social Scientists (SPSS) version 11. A regression analysis technique to study the linear relationship between the variables was conducted and the summary presented in tables 1 and 2. Furthermore, table 3 shows the calculated mean scores, standard deviations among the variables and Chronbach's coefficient alpha for scales reliability.

\subsection{Hypothesis 1: There is no statistically significant positive relationship between AC and OCB}

Table 1. Summary regression of affective commitment on organizational citizenship behaviour

Sig. $\mathrm{p}<0.05$

\begin{tabular}{cccccccc}
\hline Variables & Coefficient & $\mathrm{T}$ & Sig p & $R^{2}$ & Adj R & Dw & F \\
\hline AC & 0.120 & 1.63 & 0.00 & & & & \\
OCB & 7.75 & 8.95 & 0.00 & 0.13 & 0.12 & 1.58 & 11.92 \\
\hline
\end{tabular}


The $r^{2}$ of 0.13 or $13 \%$ shows a positive significant relationship between OCB and affective commitment. The durbin Watson of 1.58 shows auto-correlation existence the data. The calculated $f(3,253)=11.92$, $p<0.05$, shows a significant difference between OCB in affective commitment. To ascertain the level of contribution of the independent variable to dependent variable, coefficient was computed. The results shows that the coefficient of AC $(0.17)$ was positive and significant $(\mathrm{p}<0.05)$ to OCB. In addition, the coefficient of AC $(-0.17)$ was also negative but significant, as shown in table 1 . Therefore, we conclude that AC positively relates to OCB and thus reject the hypothesis that there is no statistically significant positive relationship between AC and OCB.

4.2 Hypothesis 2: There is no statistically significant positive relationship between AC and VTI

Table 2. Summary regression of affective commitment on voluntary turnover intentions

\begin{tabular}{ccccccccc}
\hline Variables & Coefficient & $\mathrm{T}$ & Sig p & $R^{2}$ & Adj R & Critical f & Dw & $\mathrm{F}$ \\
\hline AC & 0.63 & 1.94 & 0.53 & & & & & \\
VTI & 6.39 & 10.49 & $0.00^{*}$ & 0.22 & 0.21 & 2.60 & 1.94 & $23.29^{*}$ \\
\hline
\end{tabular}

Sig. p $<\overline{0.05}$

Evidence from the table above shows the $\mathrm{r}^{2}$ of 0.22 or $22 \%$ relationship between AC and VTI. The adjusted $\mathrm{r}^{2}$ of 0.21 was also significant when compared with the $\mathrm{r}^{2}$. The Durbin Watson of 1.94 shows no auto-correlation among the data hence the data is inconclusive. The $f(2,1255)=23.29$ was higher then critical $\mathrm{f}$ of 2.60 , thus a significant positive relationship exists between AC and VTI. The coefficient of 0.63 for AC contributed significantly to the voluntary turnover $(\mathrm{p}<=0.05$ ). Since $A C$, is seen to influence VTI, the hypothesis that there is no statistically significant positive relationship between AC and VTI is rejected.

4.3 Mean, Variance, Standard Deviation and Reliability Coefficient Alpha of Variables

Table 3. Mean, variance, standard deviation and scales reliability

\begin{tabular}{lcccccc}
\hline Scale & Mean & Variance & SD & $\begin{array}{r}\text { No of } \\
\text { Items }\end{array}$ & $\begin{array}{c}\text { No of } \\
\text { cases }\end{array}$ & $\begin{array}{c}\text { Reliability } \\
\text { Coefficients } \\
\text { (Alpha) }\end{array}$ \\
\hline $\begin{array}{l}\text { Affective Commitment } \\
\begin{array}{l}\text { Organizational } \\
\text { Citizenship Behavior }\end{array}\end{array}$ & 20.26 & 40.88 & 6.39 & 8 & 283 & 0.87 \\
$\begin{array}{l}\text { Voluntary Turnover } \\
\text { Intention }\end{array}$ & 11.15 & 6.892 & 2.6252 & 4 & 303 & 0.96 \\
\hline
\end{tabular}

This table shows the mean scores, variance, standard deviations, numbers of items and cases and the reliability coefficient alpha. The Chronbach alpha for AC, OCB and VTI are 0.87, 0.82 and 0.96 respectively which are greater than .70 as recommended by Nunnally (1978) for research in social sciences. The mean scores for OCB and VTI are 10.38 and 11.15 respectively.

\section{Discussion and Conclusion}

Findings from this study show that AC has a statistical significance positive relationship with OCB and VTI. The result that $\mathrm{AC}$ is an antecedent of OCB is supported by previous findings by other researchers of different cultural backgrounds (Meyer, et al., 1989; Cappelli and Rogovsky, 1998; Drago and Carvey, 1998; Farh et al., 1990; Pearce and Gregersen, 1991; Samuel and Aubrey, 2006; Chien and Su, 2009; Su and Hsiao, 2005; Ogba, 2006). AC is also found to influence VTI and this result has support from previous findings (Allen et al., 2003; Meyer and Smith, 2000; Rhoades et al., 2001; Thompson and Prottas, 2005; Gaan, 2008; Ali and Baloch, 2009; Addae and Parboteeah, 2008; Yeoh et al., 2010; Ahmad and Omar, 2010).

The lack of affective commitment among employees puts any organization in jeopardy, especially, in times of intense competition, change resulting in mergers and acquisitions. A higher level of employee's affective commitment lowers the propensity of intention to quit and also has impact on citizenship behaviors and job performance (Tett and Meyer, 1993; Shore and Wayne, 1993; Somers, 1995; Stinglhamber and Vandenberghe, 2003). A dynamic sector like the Nigerian banking sector, faces series of human capital challenges. The banks should evolve actionable strategies that focus on the acquisition, transformation, optimization and utilization of 
human capital for sustainable competitive advantage. Result-oriented human resource strategies are needed to enable employees, especially, top performers to be affectively committed to organizations. Today's organizations must ensure that they invest strategically in human capital, provide enabling environment and engage in innovative human resource management practices that take individual needs and circumstances into consideration.

The critical success and sustainability factor for the post-consolidation era Nigerian commercial banks in particular and other companies in general is having intrapreneurs as employees who are adaptive, creative, innovative, proactive, strategic in thinking, passionate and life-long learners. Fostering AC across organizational levels could help to develop and unleash the intrapreneurial potentials of employees thereby enabling them to contribute maximally to the long-term growth, development and sustainability of organizations.

\section{Organizational and Managerial Implications}

Organizations incur huge cost as a result of high turnover rates. These include: sepration, replacement, training and vacancy cost (Cascio, 1991; Hom and Griffeth, 1995; Terez, 2000). It is common for managers to believe that turnover intentions and actual turnovers occur due to dissatisfaction with pay. A survey of managers revealed that $89 \%$ of them believe employees leave for more money (Branham, 2005). However, this survey found that $88 \%$ of employees leave for reasons other than money. According to the survey, the 10 most frequently mentioned issues that employees say company do poorly are:

a. Poor management—uncaring and unprofessional managers; overworking staff; no respect, not listening, putting people in wrong jobs; speed over quality; poor manager selection processes.

b. $\quad$ Lack of career growth and advancement opportunities-no perceivable career paths; not posting job openings or filling from within; favoritism or unfair promotions.

c. Poor communications - problems communicating top-down and between departments; after mergers; between facilities.

d. Pay—paid under-market or less than contributions warrant; pay inequities; slow raises; favoritism for bonuses/raises; ineffective appraisals.

e. Lack of recognition - that says it all.

f. Poor senior leadership—not listening, asking, or investing in employees; unresponsiveness and isolation; mixed messages.

g. Lack of training —nonexistent or superficial training; nothing for new hires, managers, or to move up.

h. Excessive workload—doing more with less; sacrificing quality and customer service for numbers.

i. Lack of tools and resources_insufficient, malfunctioning, outdated, equipment/supplies; overwork without relief.

j. Lack of teamwork-poor coworker cooperation/commitment; lack of interdepartmental coordination

Another survey (NDIC, 1991) of banking industry manpower found that there was dearth of skilled manpower, high labor turnover, staff poaching and recruitment of inexperienced staff. These challenges are more acute in the $21^{\text {st }}$ century Nigerian post-consolidation banking sector. It is, therefore, essential for managers to note that the ten factors identified above are those that inhibit AC and OCB and which trigger employees' intention to quit, leading eventually to actual turnover. Organizations and their managers and supervisors all have distinct roles to play in engendering such practices, climate and culture that encourage employee AC which leads to discretionary behaviors and intention to stay. Requiring employees to work long hours is unlikely to be the solution but a strategic investment in human capital, congenial and supportive environment and innovative human resource practices that take individual employee's needs and circumstances into consideration would aid the building of affective commitment and encourage them to continue with the organization.

\section{References}

Abrams, D., Ando, K., \& Hinkle, S. (1998). Psychological attachment to the group: Crosscultural differences in organizational identification and subjective norms as predictors of workers' turnover intentions. Personality and Social Psychology Bulletin, 24(10), 1027-1039. http://dx.doi.org/10.1177/01461672982410001

Addae, H. M, Parboteeah, K. P., \& Davis, E. E. (2006). Organizational commitment and intentions to quit: An examination of the moderating effects of psychological contract breach in Trinidad and Tobago. International Journal of Organizational Analysis, 14(3), 225-238. http://dx.doi.org/10.1108/19348830610823419 
Addae, H. M., \& Parboteeah, K. P. (2008). Role Stressors and Organizational Commitment: Public Sector Employment in St Lucia. International Journal of Manpower, 29(6), 727-743. http://dx.doi.org/10.1108/01437720810904220

Ahmad, A., \& Omar, Z. (2010). Perceived family-supportive work culture, affective commitment and turnover intention of employees. Journal of American Science, 6(12), 839-846.

Akinbode, G. A. (2011). Demographic and dispositional characteristics as predictors of organisational citizenship behaviour (An appraisal of OCB in a non-English culture workgroups). Ife PsychologIA, 19(1), 375 - 403.

Alexandrov, A., Babakus, E., \& Yavas, U. (2007). The effects of perceived management concern for frontline employees and customers on turnover intentions: moderating role of employment status. Journal of Service Research, 9(4), 356-371. http://dx.doi.org/10.1177/1094670507299378

Ali, N., \& Baloch, Q. B. (2009). Predictors of Organizational Commitment and Turnover Intention of Medical Representatives (An Empirical Evidence of Pakistani Companies). Journal of Managerial Science, 3(2), 263-273.

Allen, D. G., Shore, L. M., \& Griffith, R. W. (2003). The Role of Perceived Organizational Support and Supportive Human Resource Practices in the Turnover Process. Journal of Management, 29, 99-118. http://dx.doi.org/10.1177/014920630302900107

Allen, D., Shore, L., \& Griffeth, R. (1999). A model of perceived organizational support. Unpublished manuscript, University of Memphis and Georgia State University.

Allen, N. J., \& Meyer, J. P. (1990). The measurement and antecedents of affective, continuance, and normative commitment to the organization. Journal of Occupational Psychology, 53, 1-18. http://dx.doi.org/10.1111/j.2044-8325.1990.tb00506.x

Allen, N. J., \& Meyer, J. P. (1993). Organizational commitment: Evidence of career stage effects? Journal of Business Research, 26, 49-61. http://dx.doi.org/10.1016/0148-2963(93)90042-N

Allen, N. J., \& Meyer, J. P. (1996). Affective, continuance and normative commitment to the organization: An examination of construct validity. Journal of Vocational Behaviour, 49, 252-276. http://dx.doi.org/10.1006/jvbe.1996.0043

Angle, H., \& Perry, J. (1983). Organizational commitment: Individual and organizational influences. Work and Occupations, 10(2), 123-146. http://dx.doi.org/10.1177/0730888483010002001

Arnold, H. J., \& Feldman, D. C. (1982). A multivariate analysis of the determinants of job turnover. Journal of Applied Psychology, 67(3), 350-360. http://dx.doi.org/10.1037/0021-9010.67.3.350

Barard, C. I. (1938). The Functions of the Executive. Cambridge, MA: Harvard University Press.

Bateman, T. S., \& Organ, D. W. (1983). Job satisfaction and the good soldier: The relationship between affect and employee 'citizenship'. Academic of Management Journal, 26, 587-595. http://dx.doi.org/10.2307/255908

Bedeian, A., Kemery, E., \& Pizzolatto, A. (1991). Career commitment and expected utility of present job as predictors of turnover intentions and turnover behavior. Journal of Vocational Behavior, 39(3), 331-343. http://dx.doi.org/10.1016/0001-8791(91)90042-K

Bluedorn, A. D. (1982). A unified model of turnover from organizations. Human Relations, 35(2), 135-153. http://dx.doi.org/10.1177/001872678203500204

Bond, J. T., Galinsky, E., \& Swanberg, J. E. (1997). The 1997 National Study of the Changing Workforce. New York: Families and Work Institute.

Branham, L. (2005). The 7 Hidden Reasons Employees Leave: How to Recognize the Subtle Signs and Act Before It's Too Late. AMACOM publishers. Retrieved from http://iaap-hq.org/ResearchTrends/Real_Reasons_Why_Employees_Leave.htm

Buchanan, B. (1974). Building organizational commitment: The socialization of managers in work organizations. Administrative Science Quarterly, 19, 533-546. http://dx.doi.org/10.2307/2391809

Bycio, P., Hackett, R. D., \& Allen, J. S. (1995). Further assessments of Bass's (1985) conceptualization of transactional and transformational leadership. Journal of Applied Psychology, 80(4), 468-478. http://dx.doi.org/10.1037/0021-9010.80.4.468

Cammann, C., Fichman, M., Jenkins, D., \& Klesh, J. (1979). The Michigan Organizational Assessment Questionnaire. Unpublished Manuscript, University of Michigan, Ann Arbor, Michigan. In Cook, J. D., 
Hepworth, S. J., Wall, T. D., \& Warr, P. B. (1981), The Experience of Work: A Compendium and Review of 249 Measures and their Use. New York: Academic Press.

Cappelli, P., \& Rogovsky, N. (1998). Employee involvement and organizational citizenship: Implications for laborlaw reform and lean production. Industrial and Labor Relations Review, 51, 633-653. http://dx.doi.org/10.2307/2525012

Carmeli, A., \& Gefen, D. (2005). The relationship between work commitment models and employee withdrawal intentions. Journal of Managerial Psychology, 20(2), 63-86. http://dx.doi.org/10.1108/02683940510579731

Cascio, W. F. (1991). Costing Human Resources: The financial impact of behaviour in organizations (3rd ed.). Boston, Mass.

Cheng, Y., \& Stockdale, M. S. (2003). The validity of the three-component model of organisational commitment in a Chinese context. Journal of Vocational Behaviour, 62, 465-89. http://dx.doi.org/10.1016/S0001-8791(02)00063-5

Chien, C. C., \& Su, F. C. (2009). The mediating role of job involvement in the relationship bet.ween job characteristics and organizational citizenship behavior. The Journal of Social Psychology, 149(4), 474-494. http://dx.doi.org/10.3200/SOCP.149.4.474-494

Clugston, M. (2000). The mediating effects of multidimensional commitment on job satisfaction and intent to $\begin{array}{llll}\text { leave. Journal of } & \text { Organizational }\end{array}$ http://dx.doi.org/10.1002/(SICI)1099-1379(200006)21:4<477::AID-JOB25>3.0.CO;2-7

Cook, J. D., Hepworth, S. J., Wall, T. D., \& Warr, P. B. (1981). The Experience of work: A compendium and review of 249 measures and their use. New York: Academic Press.

Cronbach, L. J. (1951). Coefficient alpha and the internal structure of tests. Psychometrika, 16, 297-334. http://dx.doi.org/10.1007/BF02310555

Dalessio, A., Silverman, W. H., \& Schuck, J. R. (1986). Paths to turnover: A re-analysis and review of existing data on the Mobley, Horner, and Hollingsworth turnover model. Human Relations, 39(3), 245-264. http://dx.doi.org/10.1177/001872678603900305

Daniels, D., Joireman, J., Falvy, J., \& Kamdar, D. (2006). Organizational citizenship behavior as function of empathy consideration of future consequences, and employee time horizon: an initial exploration using an in-basket simulation of OCBs. Journal of Applied Social Psychology, 36(9), 2266- 2292. http://dx.doi.org/10.1111/j.0021-9029.2006.00103.x

Drago, R., \& Garvey, G. (1998). Incentives for helping on the job: Theory and evidence. Journal of Labor Economics, 16, 1-25. http://dx.doi.org/10.1086/209880

Eisenberger, R., Huntington, R., Hutchison, S., \& Sowa, D. (1986). Perceived organizational support. Journal of Applied Psychology, 71, 500-507. http://dx.doi.org/10.1037/0021-9010.71.3.500

Eisenherberger, R., Fasolo, P., \& Davis-LaMastro, V. (1990). Perceived organizational support and employee diligence, commitment, and innovation. Journal of Applied Psychology, 75, 51-59. http://dx.doi.org/10.1037/0021-9010.75.1.51

Farh, J., Posdakoff, P., \& Organ, D. (1990). Accounting for organizational citizenship behavior: Leader fairness and task scope versus satisfaction. Journal of Management, 16, 705-721. http://dx.doi.org/10.1177/014920639001600404

Fishbein, M., \& Ajzen, L. (1975). Belief, attitude, intention, and behavior: An introduction to theory and research. Reading, MA: Addison. Wesley.

Freund, A. (2004). The relationship between work commitment and organizational citizenship behavior among lawyers in the private sector. The Journal of Behavioral and Applied Management, 5(2), 93-113.

Gaan, N. (2008). Stress, Social Support, Job Attitudes and Job Outcome Across Gender. The Icfai University Journal of Organizational Behavior, 52, 34-44.

Gautam, T., Dick, R., \& Wagner, U. (2001). Organisational commitment in Nepalese settings. Asian Journal of Social Psychology, 4, 239-48. http://dx.doi.org/10.1111/1467-839X.00088

Greenberg, J. (1994). Using socially fair treatment to promote acceptance of a worksite smoking ban. Journal of Applied Psychology, 79(2), 288-297. http://dx.doi.org/10.1037/0021-9010.79.2.288

Griffeth, R. W., \& Hom, P. W. (1988). A comparison of different conceptualizations of perceived alternatives in 
turnover research. Journal of Organizational Behavior, 9, $103 \quad$ - 111. http://dx.doi.org/10.1002/job.4030090202

Griffin, R. W., \& Bateman, T. S. (1986). Job satisfaction and organization commitment. In C. L. Cooper \& I. Robertson (Eds.), International review of industrial and organizational Psychology (pp. 157-188). New York: Wiley.

Guzzo, R. A., Noonan, K. A., \& Elron, E. (1994). Expatriate managers and the psychological contract. Journal of Applied Psychology, 45, 29-54.

Haque, A., \& Aslam, M. S. (2011). The influence of distributive justice on organizational citizenship behaviors: Mediating role of emotional exhaustion and organizational attachment. International Journal of Business and Social Science, 2(15), 155-165.

Hartman, C. C. (2000). Organizational Commitment: Method Scale Analysis and Test of Effects. International Journal of Organizational Analysis, 8, 89-109. http://dx.doi.org/10.1108/eb028912

Hollenbeck, J. R., \& Williams, C. R. (1986). Turnover functionality versus turnover frequency: A note on work attitudes and organizational effectiveness. Journal of Applied Psychology, 71(4), 606-611. http://dx.doi.org/10.1037/0021-9010.71.4.606

Hom, P. W., \& Griffeth, R. W. (1995). Employee Turnover. South Western College Publishing, Cincinnati, OH.

Hutchison, S. (1997). A path model of perceived organizational support. Journal of Social Behavior and Personality, 12, 159-174.

Hutchison, S., \& Garstka, M. (1996). Sources of perceived organizational support: Goal setting and feedback. $\begin{array}{lllll}\text { Journal of } \quad \text { Applied } & \text { Social }\end{array}$ http://dx.doi.org/10.1111/j.1559-1816.1996.tb00075.x

Ingram, T. N., Lee, K. S., \& Skinner, S. (1989). An empirical assessment of salesperson motivation, commitment, and job outcomes. Journal of Personal Selling and Sales Management, 9(3), 25-33.

Iverson, R. D., \& Buttigieg, D. M. (1999). Affective, normative and continuance commitment: can the 'right kind' of commitment be managed. Journal of management Studies, 36(3), $307-350$. http://dx.doi.org/10.1111/1467-6486.00138

Jones, B., Flynn, D. M., \& Kelloway, E. K. (1995). Perception of support from the organization in relation to work stress,satisfaction, and commitment. In S. L. Sauter \& L. R. Murphy (Eds.), Organizational risk factors for job stress (41-52). Washington, DC: American Psychological Association.

Katz, D. (1964). The motivational basis of organizational behaviour. Behavioural Science, 9, $131-146$. http://dx.doi.org/10.1002/bs.3830090206

Katz, D., \& Khan, R. L. (1966). The Social Psychology of Organizations. New York: NY: Wiley.

Kessels, W. M. J. (2009). Designing favourable learning environments in an emerging knowledge economy. Being a pre-conference workshop presentation at the Kigali Institute of Management, Kigali, Rwanda on 31 August, 2009.

Kim, W. C., \& Mauborgne, R. A. (1993). Procedural justice, attitudes, and subsidiary top management compliance with multinationals’ corporate strategic decisions. Academy of Management Journal, 36(3), 502-528. http://dx.doi.org/10.2307/256590

Koch, J., \& Steers, R. (1978). Job attachment satisfaction, and turnover among public employees. Journal of Vocational behavior, 12(2), 119-128. http://dx.doi.org/10.1016/0001-8791(78)90013-1

Konovsky, M. A., \& Cropanzano, R. (1991). Perceived fairness of employee drug testing as a predictor of employee attitudes and job performance. Journal of Applied Psychology, 76(5), 698-707. http://dx.doi.org/10.1037/0021-9010.76.5.698

Lambert, E. G., Hogana, N. L., \& Bartona, S. M. (2001). The impact of job satisfaction on turnover intent: A test of a structural measurement model using a national sample of workers. The Social Science Journal, 38(2), 233-250. http://dx.doi.org/10.1016/S0362-3319(01)00110-0

Lee, C. H., \& Bruvold, N. T. (2003). Creating value for employees: Investment in employee development. International Journal of Human Resource Management, 14(6), 981-1000. http://dx.doi.org/10.1080/0958519032000106173

Lee, K., Allen, N. J., Meyer, J. P., \& Rhee, Y. (2001). The three-component model of organisational commitment: 
an application to South Korea. Applied Psychology: An International Review, 50, 596-614. http://dx.doi.org/10.1111/1464-0597.00075

Lee, K., Carswell, J. J., \& Allen, N. J. (2000). A meta-analytic review of occupational commitment: Relations with person- and work-related variables. Journal of Applied Psychology, 85(5), 799-811. http://dx.doi.org/10.1037/0021-9010.85.5.799

Lee, T. W., \& Mowday, R. T. (1987). Voluntarily leaving an organization: An empirical investigation of steers and Mowday's model of turnover. Academy of Managemernt Journal, 30(4), 721-743. http://dx.doi.org/10.2307/256157

Lievens, F., \& Anseel, F. (2004). Confirmatory factor analysis and inariance of an organizational citizenship behaviour measure across samples in a Dutch-speaking context. Journal of Occupational and Organizational Psychology, 77, 299-306. http://dx.doi.org/10.1348/0963179041752727

Loi, R., Hang-yue, N., \& Foley, S. (2006). Linking employees' justice perceptions to organizational commitment and intention to leave: The mediating role of perceived organizational support. Journal of Occupational and Organizational Psychology, 79(1), 101-120. http://dx.doi.org/10.1348/096317905X39657

Luchak, A. A., \& Gellatly, I. R. (2007). A comparison of linear and nonlinear relationsbetween organizational commitment and work outcomes. Journal of Applied Psychology, 92(3), 786-793. http://dx.doi.org/10.1037/0021-9010.92.3.786

MacKenzie, S. B., Podsakoff, P. M., \& Fetter, R. (1991). Organizational behavior and objective productivity as determinants of managerial evaluations of salespersons' performance. Organizational Behavior and Human Decision Processes, 50, 123-150. http://dx.doi.org/10.1016/0749-5978(91)90037-T

Mathieu, J. E., \& Zajac, D. (1990). A review and meta-analysis of the antecedents, correlates, and consequences of organizational commitment. $\quad$ Psychological 171-194. http://dx.doi.org/10.1037/0033-2909.108.2.171

McFarlane, S., \& Wayne, S. J. (1993). Commitment ande employee behavior: Comparison of affective commitment and continuance commitment with perceived organizational support. Journal of Applied Psychology, 78, 774-780. http://dx.doi.org/10.1037/0021-9010.78.5.774

Meyer, J. P., \& Smith, C. A. (2000). HRM Practices and Organizational Commitment: Test of a Mediation Model. Canadian Journal of Administration Sciences, 17, 319-331. http://dx.doi.org/10.1111/j.1936-4490.2000.tb00231.x

Meyer, J. P., \& Allen, N. J. (1997). Commitment in the workplace: Theory, research, and application. Thousand Oaks, CA: Sage Publications.

Meyer, J. P., Paunonen, S. V., Gellatly, I. R., Guffin, R. D., \& Jackson, D. N. (1989). Organizational commitment and job performance: It's the nature of the commitment that counts. Journal of Applied Psychology, 74, 152-156. http://dx.doi.org/10.1037/0021-9010.74.1.152

Meyer, J. P., Stanley, D. J., Herscovitch, L., \& Topolnytsky, L. (2002). Affective, Continuance, and Normative Commitment to the Organization: A Meta-analysis of Antecedents, Correlates, and Consequences. Journal of Vocational Behavior, 61, 20-52. http://doi:10.1006/jvbe.2001.1842

Meyer, J. P., \& Herscovitch, L. (2001). Commitment in the workplace; toward a general model. Human Resource Management Review, 11, 299-326. http://dx.doi.org/10.1016/S1053-4822(00)00053-X

Michaels, C. E., \& Spector, P. E. (1982). Causes of employee turnover: A test of the Mobley, Griffeth, Hand, and Meglino model. Journal of Applied Psychology, 67(1), 53-69. http://dx.doi.org/10.1037/0021-9010.67.1.53

Moorman, R. H. (1991). Relationship between organizational justice and organizational citizenship behaviors: Do fairness perceptions influence employee citizenship? Journal of Applied Psychology, 76, 845-855. http://dx.doi.org/10.1037/0021-9010.76.6.845

Morrow, P. C. (1983). Concept redundancy in organizational research: The case of commitment. Academy of Management Review, 8, 486-500.

Mowday, R., Steers, R., \& Porter, L. (1982). Employee-organization linkages: The psychology of commitment, absenteeism, and turnover. New York, NY: Academic Press.

Munene, J. C. (2008). 'Not-on-seat': An investigation of some correlates of organisational citizenship behaviour in Nigeria. Applied Psychology, 44(2). http://dx.doi.org/10.1111/j.1464-0597.1995.tb01069.x 
NDIC. (1991). Report on manpower satiation in the Nigerian naming Industry. NDIC Annual Report.

Niehoff, B. P., \& Moorman, R. H. (1993). Justice as a mediator of the relationship between methods of monitoring and organizational citizenship behaviors. Academy of Management Journal, 36(3), 527-556. http://dx.doi.org/10.2307/256591

Nunnally, J. C. (1978). Psychometric theory. New York: McGraw-Hill.

O’Reilly, C. A., \& Chatman, J. (1986). Organizational commitment and psychological attachment: The effects of compliance, identification, and internalization on prosocial behavior. Journal of applied Psychology, 71, 492-499. http://dx.doi.org/10.1037/0021-9010.71.3.492

Ogba, I. (2006). Organisational measurement: exploring and developing effective exployee commitment measurement. In Neely, A., Kennerley, M., \& Walters, A. (Eds), Performance measurement and management: public and private. Centre for business performance, Bedfordshire.

Organ D. W. (1988). Organizational citizenship behavior: The good soldier syndrome. Lexington, M. A.: Lexington Books.

Organ, D. W. (1988). Organizational citizenship behavior. Lexington, MA: Lexington.

Organ, D. W., \& Konovsky, M. (1989). Cognitive versus affective determinants of organizational behavior. Journal of Applied Psychology, 74(1), 157-164. http://dx.doi.org/10.1037/0021-9010.74.1.157

Organ, D. W., \& Ryan, K. (1995). A meta-analytic review of attitudinal and dispositional predictors of

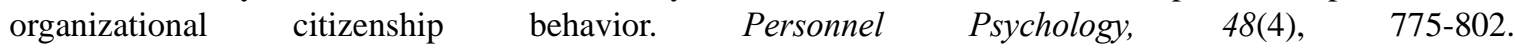
http://dx.doi.org/10.1111/j.1744-6570.1995.tb01781.x

Organ, D. W., Podsakoff P. M., \& Mackenzie, S.B. (2005). Organizational citizenship behavior: Its nature, antecedents and consequences. Sage, Thousand Oaks, CA.

Owojori, A. A., Akintoye, R. I., \& Adidu, F. A. (2011). The challenge of risk management in Nigerian banks in the post consolidation era. Journal of Accounting and Taxation, 3(2), 23-31.

Paré, G., \& Tremblay, M. (2007). The influence of high-involvement human resourcespractices, procedural justice, organizational commitment, and citizenship behaviors on information technology professionals' turnover intentions. Group and Organization Management, 32(3), 326-357.

Pearse, J., \& Grgersen, H. B. (1991). Task interdependence and extra-role behavior: A test of the mediating effects of felt responsibility. Journal of Applied Psychology, 76, 838-844. http://dx.doi.org/10.1037/0021-9010.76.6.838

Podsakoff, P. M., \& MacKenzie, S. B. (1994). Organisational citizenship behaviours and sales unit effectiveness. Journal of Marketing Research, 31, 351-363. http://dx.doi.org/10.2307/3152222

Podsakoff, P. M., Ahearne, M., \& MacKenzie, S. B. (1997). Organizational citizenship behavior and the quantity and quality of work group performance. Journal of Applied Psychology, 82, 262-270. http://dx.doi.org/10.1037/0021-9010.82.2.262

Podsakoff, P. M., MacKenzie, S. B., Moorman, R. H., \& Fetter, R. (1990). Transformational leader behaviors and their effects on followers' trust in leader, satisfaction, and organizational citizenship behaviors. Leadership Quarterly, 1, 107-142. http://dx.doi.org/10.1016/1048-9843(90)90009-7

Podsakoff, P. M., MacKenzie, S. B., Paine, J. B., \& Bachrach, D. G. (2000). Organizational citizenship behaviors: A critical review of the theoretical and empirical literature and suggestions for future research. Journal of Management, 256(3), 513-563. http://dx.doi.org/10.1177/014920630002600307

Porter, L. W., Steers, R. M., Mowday, R. T., \& Boulian, P. V. (1974). Organizational commitment, job satisfaction, and turnover among psychiatric technicians. Journal of Applied Psychology, 59, 603-609. http://dx.doi.org/10.1037/h0037335

Reich, R. B. (2001). The Future of Success. Knopf.

Rhoades, L., \& Eisenberger, R. (2002). Perceived organizational support: A review of the literature. Journal of Applied Psychology, 87(4), 698-714. http://dx.doi.org/10.1037/0021-9010.87.4.698

Rhoades, L., Eisenberger, R., \& Armeli, S. (2001). Affective commitment to the organization: The contribution of perceived organizational support. Journal of Applied Psychology, 86(5), 825-836. http://dx.doi.org/10.1037/0021-9010.86.5.825 
Sager, J. K., \& Johnston, M. W. (1989). Antecedents and outcomes of organizational commitment: A study of salespeople. The Journal of Personal Selling \& Sales Management, 9(1), 30-41.

Samuel, Y., \& Aubrey, K. (2006). Direct and indirect effects of task characteristics on organizational citizenship behavior. North American Journal of Psychology, 8(2), 253-268.

Schappe, S. (1998). Understanding employee job satisfaction: the importance of procedural and distributive justice. Journal of Business and Psychology, 12 (4), 493-503. http://dx.doi.org/10.1023/A:1025007307058

Schaubroeck, J., May, D. R., \& Brown, F. W. (1994). Procedural justice explanations and employee reactions to economic hardship: A field experiment. Journal of Applied Psychology, 79(3), 455-460. http://dx.doi.org/10.1037/0021-9010.79.3.455

Schnake, M. E. (1991). Organizational citizenship: A review, proposed model, and research agenda. Human Relations, 44, 735-759. http://dx.doi.org/10.1177/001872679104400706

Schor, J. (1991). The Overworked American. New York: Basic Books.

Schor, J. (1991). The Overworked American. New York: Basic Books.

Seashore, S., Lawler, E. Mirvis, P., \& Cammann, C. (1982). Observing and Measuring Organizational Change: A Guide to Field Practice. In Cook, J. D., Hepworth, S. J., Wall, T. D., \& Warr, P. B. (Eds.), The Experience of Work: A Compendium and Review of 249 Measures and their Use. New York: Academic Press.

Settoon, R. P., Bennett, N., \& Liden, R. C. (1996). Social exchange in organizations: Perceived organizational support, leader-member exchange, and employee reciprocity. Journal of Applied Psychology, 81, 219-227. http://dx.doi.org/10.1037/0021-9010.81.3.219

Sheldon, M. (1971). Investments and involvements as mechanisms froducing commitment to the organization. Administrative Science Quarterly, 16, 143-150. http://dx.doi.org/10.2307/2391824

Sholl, R. W. (1981). Differentiating commitment from expectancy as a motivation force. Academy of Management Review, 6, 589-599.

Shore, L. M., \& Shore, T. H. (1995). Perceived organizational support and organizational justice. In Cropanzano, R. S. \& K. M. Kacmar (Eds.). Organizational politics, justice, and support: Managing the social climate of the workplace (pp. 149-164). Westport, CT: Quorum.

Shore, L. M., \& Tetrick, L. E. (1991). A construct validity study of the survey of perceived organizational support. Journal of Applied Psychology, 76, 637-643. http://dx.doi.org/10.1037/0021-9010.76.5.637

Shore, L. M., \& Wayne, S. J. (1993). Commitment and employee behavior: Comparison of affective commitment and continuance commitment with perceived organizational support. Journal of Applied Psychology, 78, 774-780. http://dx.doi.org/10.1037/0021-9010.78.5.774

Siegel, P. H., \& Sisaye, S. (1997). An analysis of the difference between organization identification and professional commitment: a study of certified public accountants. Leadership \& Organization Development Journal, 18(3), 149-165. http://dx.doi.org/10.1108/01437739710168634

Somers, M. J. (1995). Organizational commitment, turnover, and absenteeism: an examination of direct and interaction effects. Journal of Organizational Behavior, 16(1), 49-58. http://dx.doi.org/10.1002/job.4030160107

Staples, J. G., \& Barlett, K. R. (2002). International Research on Orgaisational Commitment: An extension of Randall's 1993 Study. In Lynham, S.A., \& Egan, T.M. (Eds.), Proceedings of the Academy of Human Resource Development Conference Proceedings 2003. Minneapolis, Minnesota, February 26 - March 2, 2003.

Steers, R. M. (1977). Antecedents and outcomes of organizational commitment. Administrative Science Quarterly, 22(1), 46-56. http://dx.doi.org/10.2307/2391745

Stinglhamber, F., \& Vandenberghe, C. (2003). Organizations and supervisors as sources of support and targets of commitment: A longitudinal study. Journal of Organizational Behavior, 24, 251-270. http://dx.doi.org/10.1002/job.192

Su, F. C., \& Hsiao, L. C. (2005). Relationship between job characteristics and organizational citizenship behavior; The mediational role of job satisfaction. Social Behavior and Personality, 33(6), 523-540. http://dx.doi.org/10.2224/sbp.2005.33.6.523

Terez, T. (2000). 22 Keys Creating a Meaningful Workplace. Workplace Solutions INC. Columbus, Ohio. 
Tett, R. P., \& Meyer, J. P. (1993). Job satisfaction, organizational commitment, turnover intention, and Turnover: Path analyses based on meta-analytic findings. Personnel Psychology, 46, 259-293. http://dx.doi.org/10.1111/j.1744-6570.1993.tb00874.x

Thompson, C. A., Jahn, E. W., Kopelman, R. E., \& Prottas, D. J. (2004). Perceived Organizational Family Support: A Longitudinal and Multilevel Analysis. Journal of Managerial Issues, 16, 545-565.

Turnipseed, D. L., \& Rassuli, A., (2005). Performance perceptions of organizational citizenship behaviors at work: a bi-level study among managers and employees. British Journal of Management, 16, 231-244. http://dx.doi.org/10.1111/j.1467-8551.2005.00456.x

Ugboro, I. O. (2006). Organizational commitment, job redesign, employee empowerment and intent to quit among survivors of restructuring and downsizing. Journal of Behavioral and Applied Management, 7(3), 232-253.

Vandenberghe, C., Bentein, K., \& Stinglhamber, F. (2004). Affective commitment to the organization, supervisor, and work group: Antecedents and outcomes. Journal of Vocational Behavior, 64(1), 47-71. http://dx.doi.org/10.1016/S0001-8791(03)00029-0

Walz, S. M., \& Niehoff, B. P. (2000). Organizational citizenship behaviors and their effect onorganizational effectiveness in limited menu restaurants. Academy of Management conference, 307-31.

Wasko, M., \& Faraj, S. (2005). Why should I share? Examining knowledge contribution in electronic networks of practice. MIS Quarterly, 29 (1), 1-23.

Wasti, S. A. (2002). Affective and continuance commitment to the organisation: test of an integrated model in the Turkish context. International Journal of Intercultural Relations, 26, 525-50. http://dx.doi.org/10.1016/S0147-1767(02)00032-9

Wayne, S. J., Shore, L. M., \& Liden, R. C. (1997). A reliability coefficient for maximum likelihood factor analysis. Psychometrica, 38, 1-10.

Werner, J. M. (1994). Dimensions that make a difference: Examining the impact of in-role and extra-role behaviors on supervisory ratings. Journal of Applied Psychology, 75, 315-321.

Wiener, Y. (1982). Commitment in organizations: A normative review. Academic of Management Review, 7 , 418-428.

Williams, L. J., \& Anderson, S. E. (1991). Job satisfaction and organizational commitment as predictors of organizational citizenship and in-role behaviors. Journal of Management, 17(3), 601-617. http://dx.doi.org/10.1177/014920639101700305

Wyss, N. (2006). Shaping Success: Organizational Citizenship Behavior and its prevalence in Athlete versus Non-athlete Texas State University Student Populations. HONORS THESIS Presented to the Honors Committee of Texas State University - San Marcos In Partial Fulfillment of the Requirements For Graduation in the Mitte Honors Program San Marcos, Texas

Yeoh, S. F., Lim, C-L., \& Osman, S. (2010). An exploratory study on turnover intention among private sector employees. International Journal of Business and Managemen, 5(8), 57-64.

Zannad, H., \& Rouet, V. (2003). Organizational commitment in innovative companies. Proceedings of the XIIème Conférence de l'Association Internationale de Management Stratégique, held at Les Côtes de Carthage from 3-6, June 2003

Zeidan, S. (2006). Workers' affective commitment and their willingness to perform discretionary work behaviour: the impact of commitment-oriented human resources management practices. Journal of Business Systems, Governance and Ethics, 1(1), 13-23. 